\title{
An Attempt of Returning Assets from Corruption in The Form of Tourist Attraction
}

\author{
Muh Sutri Mansyah \\ Faculty of Law \\ University of Brawijaya \\ Malang, Indonesia \\ muhsutrimansyahr@gmail.com
}

\begin{abstract}
Indonesia is currently facing the problem of corruption that has been rampant and has a tremendous negative impact hence it is necessary eradication and prevention of corruption but in reality the resulting loss of corruption becomes a problem also, so this paper aims to describe the effort of Indonesia in retrieving the asset lost in corruption in the form of tourist attractions within the framework of legislation, this paper uses literature research based on literature. The results of this paper argue that the return of assets in the form of places that are the result of corruption becomes a challenge for Indonesia because considering the impacts resulting from the return of assets will arise problems such as management that must be reconstructed so it needs to continue to be done massively but given the corruption has spread in the system of government from the village level to the central government so that in the eradication and prevention of corruption faced obstacles and need serious handling and this is proved by the results of reports from Indonesia Corruption Watch (ICW) states approximately Rp 3 trillion total state losses and corruption cases throughout 2017, although Indonesia has institutions that focus on eradicating and preventing corruption such as police, prosecutors and KPK. Therefore, collective cooperation is required to eradicate corruption and to save assets in the form of places in Indonesia.
\end{abstract}

Keywords—return; corruption; assets; tourist place

\section{INTRODUCTION}

Indonesia is a country based on law, it is stated in Article 1 paragraph (3) of the Constitution of the Republic of Indonesia which reads "Indonesia is a State of Law" so the state law has a purpose to ensure the certainty, justice, and expediency. As well as human rights are upheld and guaranteed that everyone equally does not see from one's stratification. In this case, Article 27 Paragraph (1) of the 1945 Constitution of the State of the Republic of Indonesia which reads as follows: "All the state is in law and government and shall uphold the law and government with nothing except".

The realization of a legal state should be a driving force to protect the entire nation of Indonesia and realize prosperity, this is for the achievement of security and order in the community so that in the dynamics in the legal community remains a full legal supremacy intact. In the current globalization [1,2] of the development of science and technology is growing rapidly this is in harmony with the state of Indonesia, so the problem is growing complex and also the problems that require formulation in the current period.

One of main problems in Indonesia is corruption, a continuing problem in Indonesia to date. Corruption is categorized as one of the most extraordinary forms of crime in which the majority perpetrators are those who exercise high positions within the state structure and are not directly known as white-collar crimes. According to EH Sutherland the crime of White-collar Crimes is a real crime that violates the law by not only the small people who have inadequate living, but also slowly by the respectable, high-status social elements. Here EH wants to provide a stronger foundation with the theory that he developed, namely the theory of differential association [3].

Losses caused by corruption may be material or nonmaterial damages, but certainly in the case of state austerity savings may use a variety of ways, one of which the loss of corruption can be done through asset deprivation so that goods are not carried away, transferred, or traded . Consideration should not only focus on law enforcement on the perpetrators of corruption but also other actions to take and seize assets. Assignment of lost assets in corruption has been legitimated in Law Number 31 Year 1999 in relation to Law no. 20 Year 2001 on Corruption Eradication. Therefore, this study aims to assess the return of state assets due to acts of corruption in the form of tourist attractions.

\section{METHOD}

In this study, normative juridical approach that examines and analyzes primary data and secondary data as supporting primary data such as library materials was used. The legislation approach, in this case, is conducted by reviewing the applicable laws and regulations in Indonesia, especially those related to the return of assets in the form of tourist attractions as a result of criminal acts of corruption. As well as studying there is consistency and conformity between a law with other laws or between law and constitution or between regulation and law [4]. Conceptual approach, an approach that will examine the concepts related to asset recovery efforts in the form of tourist attractions as a result of criminal acts of corruption as has become the focus of legal issues related to the theme of research. Primary legal material as the main material used in research consisting of legislation, minutes or decisions, such as Criminal Procedure Code, Law Number 30 Year 1999 Jo, Law 
Number 20 Year 2001 on Corruption Eradication, Book of Civil Law,. Secondary law material used is data which is closely related to primary data which is used to help analyze the primary law material. This material of secondary law was obtained from books, legal journals, scholar's opinions, scientific articles both print and electronic.

\section{RESUlt AND DisCUSSION}

State losses from corruption cases continue to rise. During 2001-2015, for example, the value of losses reached Rp203.9 trillion. While throughout 2017 reached Rp3 trillion. The result of this corruption is mostly enjoyed by state officials, ranging from ministers, regional heads, members of the House of Representatives, directors of SOEs, and others [5]. These losses will add to the burden of the state, even though the funds come from the State Budget (APBN), one of which is collected from borrowing loans from other countries so that it also adds to the debt of Indonesia.

It should be noted that corruption from year to year poses a threat to the Indonesian state, according to Sritua Arief [6], corruption creates 4 negative effects that have plagued the socio-economic life First, the development of consumptive instinct to all levels of society caused by throwing hot money or black income expenditure (black income) by the perpetrators of corruption and the accompanying demonstration effect. Secondly, the transfer of national resources abroad by corrupt perpetrators is caused by concerns about the explosive social turmoil in. domestic. This makes the economic capacity of countries with corrupt governments very weak in meeting the demands of society in its development process,

Third, revenue shifts are more regressive after taking into account revenue from unrecorded corruption. Revenues from corrupt and hidden outcomes and other hidden deviations cause these revenues not to be included in the network of direct taxation objects. Fourth, social narrowing in the utilization of services of social property/goods and public services. This occurs as a result of a process of improper pricing of services in a society arising from the existence of mismatch in terms of supply and demand. Therefore, in the handling of corruption must be done remarkably considering the corruption as extraordinary crimes, and remember the losses resulting from corruption in large amounts so there needs to be a way for corruption losses can be minimally minimized even though the loss is not all returned as before, then the asset seizure became one of the efforts to restore the state losses. The reversal of the proceeds of corruption has occupied an important position in eradicating corruption. That is, the success of the eradication of corruption is not only measured by success on the criminal prosecution of corruption perpetrators, but also by the success rate of return of state assets that are corrupted [7].

The essence of eradication of corruption can be divided into 3 (three) things through preventive action, repressive and restorative action. Preventive action related to the existence of corruption eradication arrangements in the hope that people do not commit a criminal act of corruption. Restorative action where one of them is the return of assets perpetrators of criminal acts of corruption in the form of criminal law and civil lawsuits [8].
Furthermore, in the handling of corruption must be done remarkably considering the corruption as extraordinary crimes, and remember the losses resulting from corruption in a large amount so there needs to be a way for corruption losses can be minimally minimized even though the loss is not all returned as before, then the asset seizure became one of the efforts to restore the state losses. The reversal of the proceeds of corruption has occupied an important position in eradicating corruption. That is, the success of eradicating corruption is not only measured by the success of criminal prosecution of corrupt perpetrators, but also by the success rate of return of corrupted state assets.

The scope of the definition of assets is regulated in article 499 Civil Code (KUHPer), which is called material, that is each goods and each right, which can be controlled by property rights. Material according to its form, distinguished into bodied bodies and not bodied. Meanwhile, by its nature, objects are distinguished into moving objects that are spent and cannot be spent, and objects are not moving [9]. While the tourist attractions as a bodied body that have nature that cannot be spent and does not move.

Yanuar formulates the definition of the return of assets resulting from the criminal act of corruption, namely: "The system of law enforcement conducted by the state victim of corruption crime to revoke, seize and eliminate the right to the assets of corruption proceeds from the perpetrators of corruption and acts through a series of processes and mechanisms, both criminal and civil, the assets of the proceeds of criminal acts of corruption, assets resulting from criminal acts of corruption, both inside and outside the country are traced, frozen, seized, confiscated, handed over and returned to the victim country from the proceeds of corruption, loss of state finances resulting from criminal acts of corruption and to prevent perpetrators of corruption by using corrupt assets as a means or means to commit other crimes and provide a deterrent effect to perpetrators and/or potential perpetrators of corruption [10].

From this formula, there are important elements of return of assets resulting from criminal acts of corruption, namely [10]:

1) Asset return is a system of law enforcement.

2) The law enforcement is carried out either through criminal lane and civil lane

3) Through both lines the assets of corruption proceeds are tracked, frozen, seized, confiscated, handed over, and returned to the state

4) Tracking, suspending, confiscation, seizure, surrender, and return within the foreigner

5) The system of law enforcement is carried out by the state exercised by law enforcement agencies

6) The system has the following objectives:

- Restoring state losses incurred by corrupt perpetrators

- Prevent the use or utilization of such assets as a tool or means by perpetrators of criminal acts of corruption to commit other criminal acts

- Providing a deterrent effect to other parties who intend to commit a criminal act of corruption 
Asset returns include asset recovery as well, Recovery of assets is the process of handling integrated asset proceeds at each stage of law enforcement, so that the value of the asset can be retained and returned fully to the victims of the crime, including to the state. Asset recovery also includes all preventive measures to keep the asset value from being reduced [11]. The return of stolen asset recovery is crucial for the development of developing countries because the return of stolen assets does not merely restore state assets but also aims to uphold the rule of law in which no one is immune to law [7].

In executing the return of assets in the form of tourist attractions that are the result of criminal acts of corruption equal to the return of assets such as others which have been regulated in positive law in Indonesia namely, Act No . 31 of 1999 in conjunction with Law no. 20 Year 2001 on the Eradication of Corruption;

The Corruption Act provides two ways with regard to the appropriation of assets resulting from criminal acts of corruption that cause financial losses to the state or the economy of the country. The two roads that are meant are seizure through criminal lane and seizure through civil lane, among others [12]:

- Return of assets resulting from criminal acts of corruption through criminal offenses. In Article 38B paragraph (2) of the Corruption Eradication Act if the defendant cannot prove that the property as intended is obtained is not a criminal act of corruption, such property shall be deemed to be also obtained from a criminal act of corruption and the judge is authorized to decide the whole or part of the property the object is seized for the state.

- Return of Assets through the Civil Code. In addition to the return of assets resulting from corruption through criminal offenses, in the Law on Corruption Eradication there are also seizures of assets resulting from corruption through civil litigation. In the AntiCorruption Eradication Act, the return of corruption assets through a civil suit is an alternative way when the asset's seizure through criminal prosecution cannot be done for reasons justified by the law, such as a suspect or defendant dies in the case of the death of a suspect or defendant causing the loss of demanding authority [9].

Provisions related to the return of assets through civil suits are regulated in Article 32 of Act No. 31 of 1999 in conjunction with Law no. 20 Year 2001 on the Eradication of Corruption. as "In the case of an Investigator find and argue that one or more elements of corruption do not have sufficient evidence, whereas in fact there is a loss of state finances, the investigator immediately submits the case of the investigation proceedings to the state attorney's attorney for a civil suit or submitted to the institution which is injured to file a lawsuit"

From the provisions contained in article 32 paragraph (1), it can be seen that the Attorney Lawyers of State or Agencies who suffered losses must file a civil lawsuit, if in conducting an investigation, investigators find and argue [13]:
- One or more of the elements of corruption is not sufficient evidence;

- There has been a real financial loss for the state

a) Ad. A: If the investigator in conducting an investigation finds and believes that one or more of the elements of corruption is not sufficient evidence, then the act committed by the suspect is not a criminal act of corruption, but is a civil act. As a civil action, an act committed by the original suspect may, if there is sufficient evidence, constitutes an unlawful act (Article 1365 Civil Code), subsequently by a State Attorney Attorney or an aggrieved institution shall be the legal basis for filing a civil suit.

In Arrest Hoge Raad on 31 January 1919 [14], followed by the Indonesian court, misalanya in the High Court of Surabaya Decision dated December 31, 1951 Number 92/1950 Pdt [15], stated that an act is called unlawful if:

- Violates the rights of others, or

- Contrary to the author's legal obligations, or

- Contrary to good decency, or

- Contrary to the propriety found in the society of self or others' goods.

Thus, if the investigator in conducting an investigation finds and believes that one or more of the elements of corruption are insufficient, the results of the investigation shall not be an impediment to the State Attorney or the aggrieved institution to file a civil lawsuit provided there is sufficient evidence that the acts committed by originally the suspect is an act against the law.

b) Ad. B: Elucidation of Article 32 Paragraph (1) states that what is meant by "there is a real loss of the state" is the loss of megara which can be calculated in number based on the findings of the authorized institution or the appointed accountant.

- What is meant by the accountant appointed by itself is the accountant appointed by the investigator.

- With the explanation, then to determine how the amount of state losses need to be submitted evidence in the form of expert information (Article 184 paragraph (1) letter b KUHAP) [13].

Although the effort to return the assets as a form of rescue losses resulting from corruption but in the return of assets in the form of tourist attractions there is a problem that is with the return of these assets tourist attractions cannot operate considering the sights have been confiscated so that people who want to visit the sights cannot enjoy it, while if the enjoyment can be done after transferred to the related parties and has had a fixed decision, according to the author actually this should be considered by law enforcers (KPK, Police, and Attorney) given the principle of expediency ruled out when this is a public interest that should be a top priority in seizure of tourist attractions. 
The law is as useful to the community. As a part of the ideological idea (idea des recht), justice and legal certainty require a complementary benefit. Utilization can be defined as happiness. The good of a law depends on whether the law is given happiness or not to humans. The good law is the law can bring happiness or not to humans. Good law is a law that can benefit any legal subject, a law that can already be categorized well if it is able to give the happiness of the greatest part of society. Communities expect benefits in the implementation and enforcement of the law. The law is for human so the implementation of law or law enforcement should be able to avoid the occurrence of riots within the community. Good law is the law that brings benefit here can also be interpreted with happiness. Communities will obey the law without resorting to sanctions if people benefit [16].

\section{CONCLUSION}

Corruption has greatly damaged the state both materially and immaterial, so it is necessary to rescue it if it can restore the losses suffered by the state then one of the ways with the return of assets in the form of tourist attractions as a result of corruption can be done through the act of repression, in this case can Covering civil or criminal lane but the problem is the tourist spot is a place that is often visited by people who come from various regions, this also must be considered also the benefits, although it was the seizure of this effort is done in order to prevent things that are not desirable as damaged, loss and others to keep the confiscated goods, of course, if people want to enjoy the sights takes a long time until it has finally been transferred to the authorities in this case can be local government or central government as well waiting until a permanent court decision. The concerns of law enforcement officers (KPK, Police, and Attorney) who consider that will be damaged or lost can be ruled out and the authors propose that as long as the seized tourist sites must be supervised by law enforcement officers in the place so that the sights are still operated and visited by community but also the management of tourist attractions.

\section{ACKNOWLEDGEMENT}

The author would like to thank all the parties who have helped and contributed in the writing of this article, both those who contribute in the form of funding and critical ideas. Hopefully this paper can be useful theoretically and practically for the addition and development of knowledge, especially in the field of legal science.

\section{REFERENCES}

[1] M. Albow, Globalization, Knowledge, dan Sosiety, London: Sage, 1990, $\mathrm{p} 9$

[2] R. H. Huratak, Penanggulangan Kejahatan Korporasi Melalui Pendekatan Restoratif Suatu Terobosan Hukum, Sinar Grafika, 2013., p. 1.

[3] Sahetapy, J. E., Kejahatan Korporasi, Eresco, Bandung, 1994.

[4] Marzuki, P. M., Penelitian Hukum Edisi Revisi, Kencana, Jakarta. 2013.

[5] Harian Terbit, Negara Rugi Ratusan Triliun Akibat Korupsi, KPK Didesak Bongkar Kekayaan Tidak Sah Pejabat. Available at: https://nasional.harianterbit.com/nasional/2018/01/27/92744/25/25/Nega ra-Rugi-Ratusan-Triliun-Akibat-Korupsi-KPK-Didesak-BongkarKekayaan-Tidak-Sah-Pejabat. 07 Februari 2018.

[6] S. Arief, Korupsi, Lembaga Studi Pembangunan, Jakarta. 1986.

[7] Badan Pembinaan Hukum Nasional Deprtemen Hukum dan Hak Asasi Manusia RI, 2009, Laporan Lokakarya tentang Pengembalian Aset Negara Hasil Tindak Pidana Korupsi, Jakarta.

[8] Erna, B. M., Peranan Jaksa dalam Pengembalian Aset Negara, Seminar Nasional Optimalisasi kewenangan Kejaksaan dalam pengembalian Aset hasil Korupsi melalui Instrumen Hukum Perdata, Paguyuban Pasundan, FH Universitas Pasundan, Bandung. 2013.

[9] Anti-Corruption Clearing House, Aset Koruptor, Mengapa Harus Disita? Available at: https://acch.kpk.go.id/id/artikel/fokus/aset-koruptormengapa-harus-disita. 07 Februari 2018.

[10] Yanuar, P. M., Pengembalian Aset Hasil Korupsi: Berdasarkan Konvensi PBB Anti Korupsi 2003 Dalam Sistem Hukum Indonesia, Alumni, Bandung. 2007.

[11] Widyopramono, Peran Kejaksaan Terhadap Aset Revocery Dalam Perkara Tindak Pidana Korupsi", Pelatihan Hukum Pidana dan Kriminologi "Asasasas Hukum Pidana dan Kriminologi serta Perkembangannya Dewasa ini, Kerjasama MAHUPIKI dan Universitas Gadjah Mada, Yogyakarta. 2014.

[12] S. E. Iskandar, Prinsip Pengembalian Aset Hasil Korupsi (Bagian VI). Available at: https://gagasanhukum.wordpress.com/2008/09/29/prinsippengembalian-aset-hasil-korupsi-bagian-vi/. 06 Februari 2018

[13] Wiyono, R, Pembahasan Undang-Undang Pemberantasan Tindak Pidana Korupsi, Sinar Grafika, Jakarta. 2005.

[14] S. Rachmat, Tinjauan Elementer Perbuata Melanggar Hukum, Bina Cipta, Bandung. 1991.

[15] A. Chidir, Yurisprudensi Indonesia tentang Perbuatan Melanggar Hukum, Bina Cipta, Bandung. 1978.

[16] W. Tata, Asas Kepastian Hukum, Keadilan, dan Kemanfaatan Dalam Kaitannya Dangan Putusan Kepailitan Pengadilan Niaga, Jurnal Dinamika Hukum, Vol. 14 No. 2 Mei 2014. 